\title{
Topic Trends in Educational Technology Research (2015-2020)
}

\section{Özlem CANAN GÜNGÖREN* \\ Zeliha DEMIR KAYMAK ${ }^{* *}$ \\ Onur İŞBULAN ${ }^{* * *}$ Bayram TOK ${ }^{* * * *}$ Fatma SAVAŞ ${ }^{* * * *}$ \\ Sedef YILDIRIM ${ }^{* * * * * *} \quad$ Nermin ELİBOL \\ Sedat TUFANÇLI ${ }^{* * * * * * *}$ Elif ÇiVi் ${ }^{* * * * * * * *}$ İsa ÖZTÜRK ${ }^{*}$}

\begin{abstract}
This study aimed to determine the subject trends of the articles published in educational technology in recent years. For this purpose, the articles' titles and keywords in 10 academic journals, including Australasian Journal of Educational Technology, British Journal of Educational Technology, Computers \& Education, Computers in Human Behavior, Educational Technology Research and Development, Interactive Learning Environments, Journal of Educational Technology \& Society, Learning, Media and Technology, Social Science Computer Review and Technology, Pedagogy and Education that published articles in educational technology in 20152020, were examined. In the analyses conducted, it was observed that the three most used words in the headings were learning, social and online. It was discovered that the most used concepts as keywords were Social Media, Interactive Learning Environment / Environments, and Teaching / Learning Strategies. In terms of education level, researches were conducted the most at the Higher education level and the least at the Pre-school and Primary school level.
\end{abstract}

Keywords: Educational technology, trend, journals.

\footnotetext{
* Orcid ID: https://orcid.org/0000-0002-9184-6110, Assoc. Prof. Dr., Sakarya University, Turkey, ocanan@sakarya.edu.tr

** Orcid ID: https://orcid.org/0000-0002-9317-9198, Assist. Prof. Dr., Sakarya University, Turkey, zelihad@sakarya.edu.tr

${ }^{* * *}$ Orcid ID: https://orcid.org/0000-0001-5326-071X, Assist. Prof. Dr., Sakarya University, Turkey, oisbulan@sakarya.edu.tr

${ }_{* * * * *}$ Orcid ID: https://orcid.org/0000-0001-8040-9903, Sakarya University, Turkey, bayram.tok@ogr.sakarya.edu.tr

${ }^{* * * * *}$ Orcid ID: https://orcid.org/0000-0002-8361-6585, Sakarya University, Turkey, fatma.savas@ogr.sakarya.edu.tr

****** Orcid ID: https://orcid.org/0000-0001-7974-1941, Sakarya University, Turkey, sedef.yildirim1@ogr.sakarya.edu.tr

${ }^{* * * * * * *}$ Orcid ID: https://orcid.org/0000-0002-5252-6317 Sakarya University, Turkey, nermin.elibol1@ogr.sakarya.edu.tr

********* Orcid ID: https://orcid.org/0000-0002-6282-1117, Sakarya University, Turkey, sedat.tufancli@ogr.sakarya.edu.tr

********* Orcid ID: https://orcid.org/0000-0002-0817-6954, Sakarya University, Turkey, elif.civi1@ogr.sakarya.edu.tr

*********** Orcid ID: https://orcid.org/0000-0003-3314-7378, Sakarya University, Turkey, isa.ozturk1@ogr.sakarya.edu.tr
} 


\section{INTRODUCTION}

As it is known, it is possible to see a technology-related tool in every field we meet our needs in, such as using mobile phones for communication we talk about today. Although many people think technology originated with computers and other electronic devices, technology is an ancient concept. In the most general sense, technology is expressed as creating functional structures necessary to dominate nature by employing acquired skills (Alkan, 2011).

It seems that every technology requires a unique division of labor, specialization, and working order. Technology helps people benefit more effectively and efficiently from the knowledge and skills acquired through education and apply them more systematically and consciously. On the other hand, it is seen that, as education affects technology, technology also affects educational practices in every field. Thus, the importance of the relationship between education and technology is mentioned.

Technology has started to be used to reveal information and transfer information rather than classroom environments equipped with technology (Kurt, 2019). On the one hand, creating significant brains in subjects such as big data, digital glasses, the internet of things (IoT), 3D printers, and focusing on the big picture can be achieved through technology-based studies (Öztemel, 2018).

Using a technology tool in the classroom environment, which also considers the learner's characteristics, will make information to be understood better. Researches have revealed that using technology tools in-class educational institutions can be more effective. The lesson can be more attractive and contribute to the students' behavioral development, and increase their motivation (Lai \& Bower, 2019).

In the 21st century, educational environments are maintained not only face to face but also in online systems. An effective teaching and learning process in an online learning platform is necessary to benefit from the possibilities of technology. While designing the online platform, creating the content by integrating the technology into the system to increase students' motivation and enable them to use the system in line with their characteristics (Shukla, Dosaya, Nirban, \& Vavilala, 2020). With the advancement of artificial intelligence technologies, many facilities such as personalized learning environments, adaptive learning, virtual reality, and automatic grading systems have started to be used in learning-teaching processes in contemporary educational environments (Yufei, Saleh, Jiahui, Mohamad, \& Abdullah, 2020).

\section{Educational Technology}

The concept of educational technology is generally defined as the use of technology in an academic environment. In the 1960s, the idea of "educational technology" emerged in the USA to meet the demands in education and use technological resources more efficiently to eliminate problems in education (Numanoğlu, 1995). There have been various definitions of educational technology in the literature from past to present. With the development of technology, changes are seen in these definitions. 
According to Dieuzeide (1971), educational technology is the body of information obtained by applying learning-teaching processes to real-life conditions through the classroom environment. All kinds of tools, methods, and techniques developed in this process also aim to help this application. Cleary (1976) expresses educational technology as all research methods and techniques that have been created for the application of teaching principles. In this context, Cleary's statement supports Dieuzeide's argument in this respect.

Educational Technology is a study and practice to facilitate the learning-teaching process by creating appropriate technological processes and resources, using and managing technology, and increasing performance and quality (Januszewski \& Molenda, 2008). When we look at it from this aspect, we can express educational technology as using and managing the resources, processes, and methods it contains. According to Alkan (2011), educational technology is the functional structuring of learning or training processes by employing relevant knowledge and skills to dominate the general education and the learning situation. In other words, it is the design, implementation, evaluation, and development of learning-teaching processes. In line with all these definitions, educational technology can be defined as a complex and integrated systems process containing method, technique, and assistance to realize the learning-teaching functions in a quality way, putting into practice various methods, tools, and materials to enable individuals to learn at the highest level and seeking answers to the questions of "what" and "how should we teach" in the process of designing and learning-teaching environments.

As a result, the point reached has been the course content + method + environment approach prepared to achieve the determined behavioral goals. There is no doubt that such a component would require a system. In the scientific evolution process, the emergence of systems science and the determination of educational technology's concept and scope in modern terms are in the same period. The systems approach, whose outputs in engineering are space travel and atomic bombs, have been educational technology in education. So much so that the systems approach in education has become synonymous with education or instructional technology (Wittich \& Schuller, 1979, p.11). When educational technology research studies are examined, Caffarella (1999) examined the trends in doctoral dissertations completed in the United States from 1977 to 1998. In his research, he emphasized that computer-based and computer-aided teaching subjects were more frequently mentioned in the theses published on educational technologies, that the number of quantitative research methods decreased, and that the number of qualitative researches gradually increased.

On the other hand, Costa (2007) handled 254 master's theses published between 1986 and 2005. He examined them in terms of the universities where they were published, thesis numbers by years, researched themes, aims, methods, analysis techniques, and samples. As a result of the content analysis conducted according to these titles, it was revealed that theses increased over the years, researches mainly were conducted in 
schools, examinations were based on actual problems, studies were carried out for analysis and understanding purposes, materials were frequently used, non-experimental research design and qualitative research types were high in number.

Şimşek et al. (2008) examined 64 doctoral dissertations published in educational technologies in five major universities in Turkey in the last decade. The theses examined were dealt with in terms of form, content, and method. According to these dimensions, when the theses were analyzed, educational technology research's quality and quantity varied significantly according to universities. The experimental model was used more. Students in formal education were generally preferred as subjects. The concept of learning in computerized systems as a sub-concept in educational technology came to the fore, followed by instructional design variables and learning approaches. The most important result of this study was that there were no studies in Turkey on many educational technology subjects. Existing studies had problems in terms of internal and external validity.

Again, Şimşek et al. (2009) studied 259 master's theses published on educational technology between 2000 and 2007 in Turkey and discovered that most of the theses dealt with learning-teaching models and technology issues. It was stated that quantitative research design was primarily used in the theses, questionnaires, tests, and scales were frequently applied as data collection tools. Descriptive statistics, t-tests, and analysis of variance were used in data analysis. As a result of the research, it was reported that there was limited research on multimedia, curriculum evaluation, individual differences, learning strategies, assessment and evaluation, instructional design, ethical and professional difficulties, quality in education and educational communication, and that studies should focus on these issues.

Their content analysis titled Trends in Educational Technology Research in Turkey, Göktaş et al. (2012) aimed to review the methodological dimensions of the studies conducted in educational technologies published in SSCI journals to reveal their general tendencies. For this purpose, 460 articles of Turkish origin published on educational technologies between 2000-2009 in 32 international journals under SSCI in 2010 were analyzed using the content analysis method. According to the results of the analysis, it was observed that the studies mostly focused on teaching environments and technology. Quantitative methods and screening type as a research design were widely adopted in the reviewed studies. The questionnaire was applied as the data collection tool, and a purposeful sampling method was employed to determine samples. Descriptive analysis was preferred as a data analysis method.

Alper and Gülbahar (2009) revealed the trends and problems in educational technology from the Turkish Online Journal of Educational Technologies (TOJET) articles between 2003-2007. The studies selected in the research were examined based on methodologies and theories, the most and the most minor subjects, the designs that shaped the investigation, the size, the selection of the samples, the number of authors, data collection methods, and references and variables. As a result of the research, suggestions 
were made to base research studies on a theoretical frame, to use mixed research methods to complement each other, to refer to the level of k-12 as much as to higher education, to investigate interdisciplinary issues, sample selection, data collection, and research designs.

In the study titled General Trends in Master's and Doctorate Theses in the Field of Educational Technologies in Turkey, Erdoğmuş and Çağltay (2009) studied the master and doctoral theses published by all universities with masters and doctorate departments in the field of Computer and Instructional Technologies in Turkey. At the end of the study, 248 master's and doctoral dissertations were reached. These theses were examined and classified according to their methodology, sampling techniques, research environment, data collection inventories, and research topics.

Another trend study is the document analysis study conducted by Hew, Kale, and Kim (2007). In this study, the researchers examined 340 experimental research articles published between 2000 and 2004 in the Educational Technology Research \& Development journal regarding subject, research method, data collection methods, and research environment. As a result of the examination, they stated that the most researched issues were media, learning psychology, educational design approaches, and evaluation methods, that the most preferred research model was descriptive research design, and the research was primarily conducted in higher education and primary education. Surveys mainly were used in collecting data.

Another study conducted on educational technology trends is the study by Çakmak et al. (2016). In this study, 583 articles published in eight leading international journals within the scope of the Social Sciences Citation Index (SSCI) of 2014 were analyzed using the content analysis method. According to the research results, the researchers stated that the quantitative method was used the most, that the questionnaire was used the most as the data collection tool, that the convenience sampling was used for sample selection, and that the undergraduate level was the most as the sample level. They also stated that the most preferred data analysis method was the predictive analysis method, and the most studied subjects were instructional design and information technologies in education.

In Latchem (2006) study, one of the content analysis studies carried out in educational technologies in the literature, 23 editorial articles, 265 refereed articles, and 86 conference papers were reviewed with the content analysis he made on the studies on BJET magazine. As a result, it was observed that the rate of male researchers was higher than that of female researchers. It was noted that most researchers participated, respectively, from the UK, USA, Australia, Taiwan, and the Netherlands. Half of the research topics were educational technology in universities, followed by pre-school subjects. It was observed that the researches mainly were done in an experimental design. In the research, it was seen that the evaluation and observation of technology and pedagogy, the potentials and problems of new technologies, content development, 
and course design were discussed chiefly. The researchers aimed to provide an idea on the future of educational technology with this study.

Kılıç Çakmak et al. (2015) examined 617 articles published in 2013 from 6 journals (AJET, BJET, C\&E, ETR \& D, ET\&S, and L\&I), which were scanned within the scope of SSCI, with content analysis. This study aimed to examine the reviews in educational technologies in general terms. As a result of the study, the researchers discovered that the most studied subject was instructional design, the most applied method was quantitative, the most employed data collection tool was a questionnaire, the most applied sampling method was convenience sampling, the most studied sample level was undergraduate level. The most studied sample number was between 31-100.

Ross, Morrison, and Lowther (2010) conducted another trend study. In the study, they examined past and present research trends by focusing on enlightening educational practices to realize and improve schools' learning activities. In this context, in 43 articles published between 2006-2008, they mentioned effective technology usage types, past trends, alternative research types to balance internal and external validity. As a result of the research, they revealed that descriptive types mainly were used, and qualitative research types were applied more. On the other hand, they stressed that more research should be done on distance education, web-based courses, technology integration as a learning tool in classroom education, and internal and external validity.

In another study by Masood (1997), the aim was to identify the dominant themes in educational technology and concepts with increasing or decreasing effects. They analyzed 200 articles published in the last ten years, applying the content analysis method in this context. According to the research, they emphasized an increase in the number of articles in the last five years and that the most discussed topics were distribution systems and media form. This study was presented by developing a classification framework and estimating the articles published in 4 journals between 2000 and 2004 to examine educational technology studies' research approaches. It was concluded that research was increasingly dominated by experimental articles that adopted a pluralistic approach to both research methods and different types of nonexperimental research. It was stated that the articles and journals published in the researched journals were different from the ones that lead us to believe. Researchers were forced to reflect on the state of the field and how it could be further developed.

The Purpose of the Study and the Problem Statement

When the studies are considered, it is seen that there is a lot of research on educational technology. In recent years, revealing the change in the subject of the articles on educational technologies in the literature will shed light on the researchers in the educational technology field. For this reason, the present study aimed to determine the trends of recent researches on educational technology. For this purpose, the articles published in educational technology journals between 2015 and 2020 were examined, and the trend of the studies in this field was tried to be determined. 


\section{METHOD}

This research was carried out by document analysis, one of the qualitative research methods. Document analysis is a systematic data collection and analysis method used to examine and evaluate all documents, including printed and electronic materials (Kiral, 2020: 173; Bowen, 2009:27). The data were obtained from written documents available in an electronic environment determined by the research's purpose. Descriptive statistics were used to analyze the data.

Altheide and Schneider (1996) stated that the procedures to be done in document analysis studies determine the documents and the data to be used, collecting documents and data, coding data, defining analyses, analyzing data, and reporting. Within this research's scope, the documents' properties included in the study were determined first of all. For this purpose, journal publications on educational technology were examined. As a result of the examinations, it was decided to investigate the articles published in "Australasian Journal of Educational Technology", "British Journal of Educational Technology", "Computers \& Education", "Computers in Human Behavior", "Educational Technology Research and Development", "Interactive Learning Environments", "Journal of Educational Technology \& Society", "Learning, Media and Technology", "Social Science Computer Review" and "Technology, Pedagogy and Education" 10 academic journals since 2015. A total of 7,268 articles published in 10 journals were examined within the scope of the research. The document analysis method was used as the data collection method. The content analysis method was preferred for document analysis to analyze the subject to be investigated in depth. In line with the study's purpose, it was decided to collect the publication date and place of publication information, titles, and keywords of the articles and examine the obtained data with descriptive statistical methods.

\section{FINDINGS}

In this section, the findings reached after the statistical analysis of the data obtained from the articles examined within the study's scope are included. The articles reviewed were analyzed and evaluated according to the criteria of the number of articles by year, the number of articles by journal, the most used words in article titles, the most used keywords and their numbers in the articles, the most used keywords together and the number of articles according to education level.

\section{Number of Articles by Year}

Within the scope of the research, the number of journals determined in educational technology and the number of articles published in these journals are given in Table 1. 
Table 1

Number of Articles by Year

\begin{tabular}{|c|c|c|c|c|c|c|}
\hline Journals & 2015 & 2016 & 2017 & 2018 & 2019 & 2020 Q1 \\
\hline Australasian Journal of Educational Technology & 43 & 43 & 56 & 55 & 63 & 9 \\
\hline British Journal of Educational Technology & 149 & 101 & 104 & 81 & 204 & 33 \\
\hline Computers \& Education & 236 & 162 & 150 & 213 & 199 & 158 \\
\hline Computers in Human Behavior & 665 & 868 & 693 & 435 & 438 & 265 \\
\hline Educational Technology Research and Development & 44 & 59 & 75 & 70 & 68 & 25 \\
\hline Interactive Learning Environments & 46 & 124 & 72 & 74 & 79 & 15 \\
\hline Journal of Educational Technology \& Society & 115 & 108 & 95 & 87 & 24 & - \\
\hline Learning, Media and Technology & 28 & 29 & 31 & 34 & 34 & 7 \\
\hline Social Science Computer Review & 59 & 37 & 48 & 67 & 75 & 16 \\
\hline Technology, Pedagogy and Education & 35 & 34 & 39 & 40 & 37 & 15 \\
\hline Total & 1420 & 1565 & 1363 & 1156 & 1221 & 543 \\
\hline
\end{tabular}

According to Table 1, 1,420 articles were published in 2015, 1,565 articles in 2016, 1,363 articles in 2017, 1,156 articles in 2018, 1,221 articles in 2019, and 543 articles in the first quarter of 2020 .

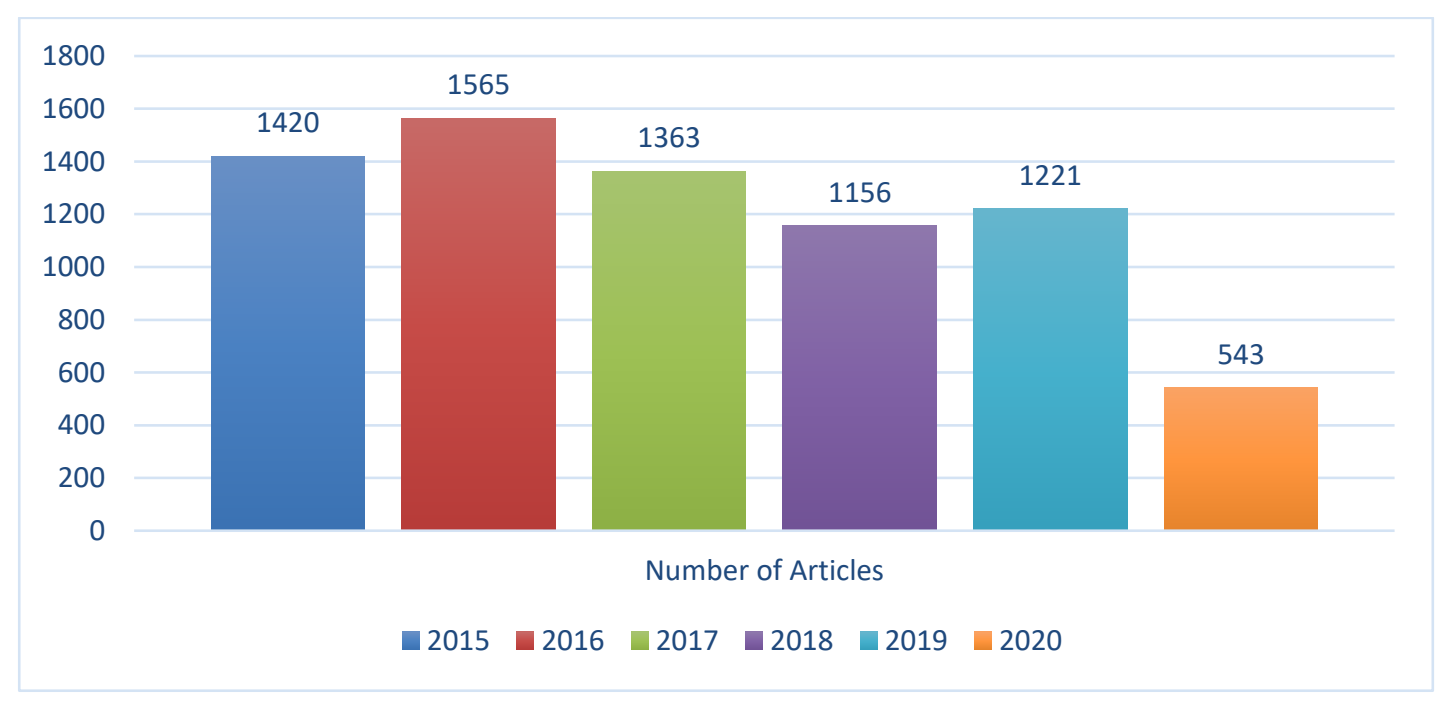

Figure 1. Number of Articles by Year 
As seen in Figure 1, the most articles were published in 2016 with 1,565, while the most minor articles were published in 2018 with 1.156. The first quarter of 2020 is not included in these statistics.

\section{Number of Articles by Journal}

The evaluation and numerical analysis of the articles examined within the scope of the research according to the journals they were published are given in Table 2 .

Table 2

Number of Articles by Journal

\begin{tabular}{lc}
\hline Journals & $\begin{array}{c}\text { Numbers of } \\
\text { Articles }\end{array}$ \\
\hline Australasian Journal of Educational Technology & 269 \\
British Journal of Educational Technology & 672 \\
Computers \& Education & 1118 \\
Computers in Human Behavior & 3364 \\
Educational Technology Research and Development & 341 \\
Interactive Learning Environments & 410 \\
Journal of Educational Technology \& Society & 429 \\
Learning, Media and Technology & 163 \\
Social Science Computer Review & 302 \\
Technology, Pedagogy and Education & 200 \\
\hline
\end{tabular}

When Table 2 is examined, it is seen that the most publications were in Computers in Human Behavior with 3,364 articles, and the least in the journal Learning, Media, and Technology with 163 articles. Computers in Human Behavior is followed by Computers \& Education with 1,118 articles. The distribution of the number of articles in other journals is British Journal of Educational Technology, Journal of Educational Technology \& Society, Interactive Learning Environments, Educational Technology Research and Development, Social Science Computer Review, Australasian Journal of Educational Technology and Technology, Pedagogy and Education when ordered from high to low.

\section{The Most Used Words in Titles}

After examining the change of the number of articles published in journals and journals by year, a numerical analysis of the words used in article titles was made and given in Table 3 . 
Table 3

The Most Used Words in Titles

\begin{tabular}{ll}
\hline Words & Numbers of Articles \\
\hline Learning & 1953 \\
Social & 1031 \\
Online & 918 \\
Use & 608 \\
Effects & 521 \\
Study & 502 \\
Using & 434 \\
Technology & 406 \\
Digital & 392 \\
Mobile & 369 \\
\hline
\end{tabular}

According to Table 3, it is seen that the most used word in the titles is "learning" with 1,953 times. This word is followed by the word "social," used 1,031 times. The word "online," used 918 times, is the third most used word in the titles. Looking at other words, the word "use" was used 608 times, the word "effect / s" 521 times, the word "study" 502 times, the word "using" 434 times, the word "technology" 406 times, the word "digital" 392 times, and the last word among the first ten words, the word "mobile" was used 369 times. The word cloud prepared for the words used in the article titles examined is also given in Figure 2.

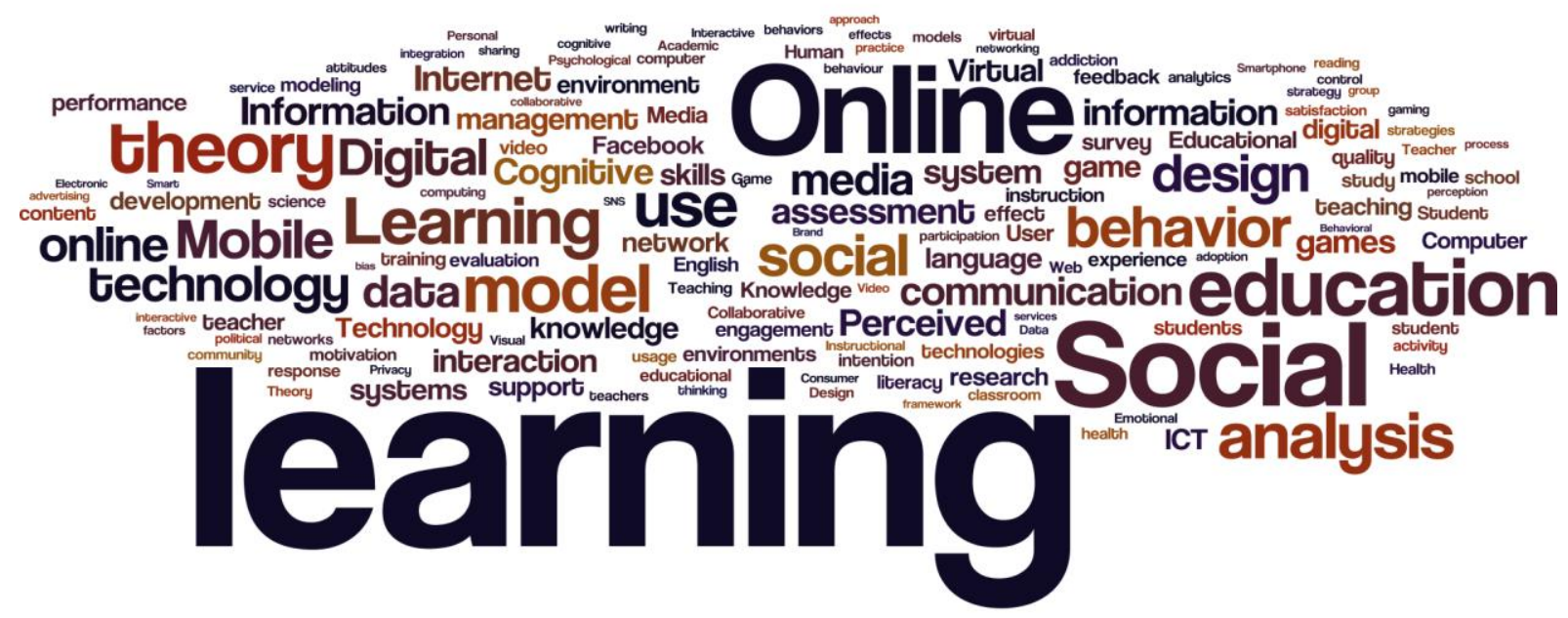

Figure 2. Word Cloud for the Words Used in Article Titles 


\section{The Most Used Keywords}

The data obtained from the published articles, the ten most used keywords and their usage frequency are given in Table 4.

Table 4

The Most Used Keywords

Keywords

1. Social Media

2. Interactive Learning Environment/Environments

3. Teaching/Learning Strategies

4. Facebook

5. Higher Education

6. Improving Classroom Teaching

7. Computer-Mediated Communication

8. Pedagogical Issues

9. Collaborative Learning

10. Media in Education
Numbers of Articles

437

258

233

226

165

163

156

134

126

124

When Table 4 is examined, it is seen that the most used keyword in the articles was "Social Media" with 416 times. Some social media tools with the most users between 2016 and 2020 are Facebook, YouTube, and Instagram, Twitter (Akademi, 2020). According to February 2020, Facebook, YouTube, WhatsApp, Instagram, and Twitter are the most used social media tools (Tankovska 2021). Among the 7,268 articles analyzed, "Facebook" was used 226 times to be associated with "Social Media" and occupied the first place. "Twitter" was used 100 times, "Instagram" 23 times, "YouTube" 10 times, and "WeChat" 9 times.

"Interactive Learning Environments" was in second place with 258 articles. The word "Learning Environment" was re-searched in the data to determine how many times other learning environments were studied in the articles from the Interactive Learning Environment / Environments keyword. The keyword "Distributed Learning Environments" related to the learning environments was used 25 times, followed by the Interactive Learning Environment / Environments keyword. The keyword "Virtual Learning Environment / Environments" was used 17 times, the keyword "Learning Environment / Environments" 12 times, the word "Computer-Based Learning 
Environment / Environments" 12 times, and the keyword "Online Learning Environment / Environments" 8 times.

"Teaching / Learning Strategies" was the third most used keyword with 233 articles. In the examined 7,268 articles, the Learning Strategies keyword was used 16 times, and the Teaching Strategies keyword was used 10 times.

The "Facebook" was used in 226 articles in the fourth rank among the ten most used keywords. A Facebook-related keyword was used in 96 of the articles examined within the scope of the research. Looking at the top 5 keywords related to Facebook, it is seen that the Facebook Addiction keyword was used in 10 articles. As for other keywords, the "Facebook Use" keyword was used in 9 articles, "Problematic Facebook Use" and "Facebook Intensity" keywords in 4 articles, and the "Passive Facebook Use" keyword in 3 articles.

The keyword "Higher Education" was used in 165 articles, ranking fifth. This keyword has different uses. These are Higher education cyberbullying, Technology-enhanced learning research in higher education, Internationalization of higher education, Malaysian higher education, Higher education management, Teaching in higher education, Chinese higher education, European higher education area, Asian higher education, Higher education setting.

The keyword "Improving Classroom Teaching" was used in 163 articles and ranked sixth. While the keyword "Computer-Mediated Communication" was used in 156 articles, the keyword "Pedagogical Issues" was used in 134 articles.

The ninth of the top 10 keywords was "Collaborative Learning," with 126 articles. Among the 7,268 articles examined, the keyword "Cooperative / Collaborative Learning," one of the keywords related to "Collaborative Learning," was used in 79 articles. Among other keywords, "Computer-Supported Collaborative Learning" was used in 42 articles and "Online Collaborative Learning" in 10 articles.

The keyword "Media in Education" was in 10th place with 124 articles. The word cloud prepared for the keywords of the articles is also given in Figure 3. 


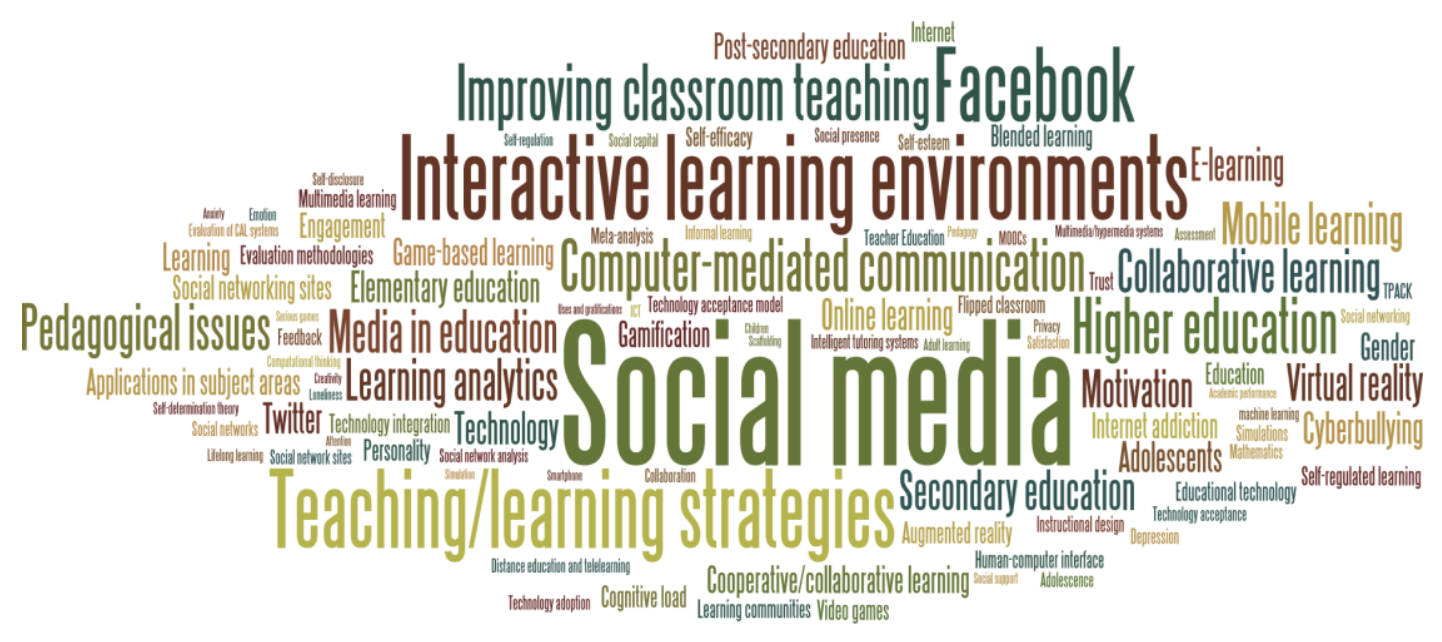

Figure 3. Word Cloud Prepared for Keywords

According to the data obtained within the scope of the research, the ten most frequently used keywords are given in Table 4. In the next step, the most used keywords and other key terms used with them were examined.

\section{The Keywords Used Together the Most}

When the three keywords used together in the keywords are examined, it is seen that the keywords "Applications in Subject Areas," "Interactive Learning Environments," and "Pedagogical Issues" were used in 10 studies (Table 5). While the keywords "ComputerMediated Communication," "Cooperative / Collaborative Learning," and "Learning Communities" were used together in four studies, in other four studies, the keywords "Teaching / Learning Strategies," "Elementary Education", and "Applications in Subject Areas" were used.

Table 5

The Keywords Used Together the Most

Keywords Numbers of Articles

Applications in Subject Areas,

Interactive Learning Environments,

Pedagogical İssues

Computer-Mediated Communication,

Cooperative/Collaborative Learning,

Learning Communities 
Teaching/Learning Strategies,

Elementary Education,

Applications in Subject Areas

When Table 5 is examined, it is seen that the keywords "Applications in Subject Areas," "Interactive Learning Environments," "Pedagogical Issues" were the keywords used together the most in 10 articles based on the first three keywords of the journals. These keywords were followed by the keywords "Computer-Mediated Communication," "Cooperative / Collaborative Learning," "Learning Communities," and the words "Teaching / Learning Strategies," "Elementary Education," "Applications in Subject Areas", with four articles per each.

\section{Education Level}

Education levels were examined in the keywords examined within the scope of the research, and the keywords with education level are given in Table 6.

Table 6

Number of Articles by Education Level

\begin{tabular}{lc}
\hline Education Level & Numbers of Articles \\
\hline Pre-school & 10 \\
Primary & 12 \\
Elementary & 115 \\
Secondary & 131 \\
Post-secondary & 89 \\
Higher & 175 \\
Adult & 32 \\
Life Long & 37 \\
\hline
\end{tabular}

When Table 6 is examined, articles using "Higher Education" as the keyword took first place with 175, while 131 articles using "Secondary Education" were in second place. As for the other education levels, "Elementary Education" was used in 115 articles, "Postsecondary Education" in 89 articles, "Adult Learning / Education" in 32 articles, "Lifelong Learning" in 37 articles. The number of articles on "Pre-school Education," the lowest education level, was 10, and the number of articles on "Primary Education" was 12. 


\section{RESULTS, DISCUSSIONS AND SUGGESTIONS}

With the increase in knowledge and population, developments and changes in science and technology have increased the importance of education and technology in the individual and social field (Alkan \& Hacıoğlu, 1995). As technology affects every aspect of our lives, recognizing its importance in education has led to increased studies on this subject and the emergence of different concepts. Accordingly, educational technology has been developed, and its importance has been emphasized with the studies. To facilitate performance, learning, and development by creating, using, and managing appropriate technological processes and resources (Januszewski \& Molenda, 2008), as well as giving importance to the application of current digital and information tools, addressing educational needs and problems, are included in the definition of educational technology (Roblyer and Doering, 2013). In this respect, educational technology and studies in this field are essential in increasing education quality. An infographic was prepared to summarize the findings obtained in this study and is presented in the appendices (Appendix 1).

Based on the importance of the studies on educational technology, when the titles of the studies in the journals accepted in the field of educational technology are examined, it is observed that the "Learning, Social, Online, Use, Effects, Study, Using, Technology, Digital, Mobile" words were used the most in the titles. Considering these words, it can be assumed that educational technology studies focus on learning, and these studies generally examine current technologies and their effects. This result contains similar results with the research done by Berrocoso, Arroyo, Videla \& Cevallos (2020) and Krull \& Duart (2017).

On the other hand, when the key concepts in these studies are examined, it is seen that "Social Media, Interactive Learning Environment/Environments, Teaching/Learning Strategies, Facebook, Higher Education, Improving Classroom Teaching, ComputerMediated Communication, Pedagogical Issues, Collaborative Learning, Media in Education" concepts were used the most. This result is similar to Greenhow, Galvin, \& Staudt Willet (2019). When these concepts are examined, it is seen that the technologies (tools, methods, techniques) that have emerged in recent years or have become widespread in recent years have been addressed in educational technology researches. It has also been observed that the concepts used together the most were Applications in Subject Areas, Interactive Learning Environments, and Pedagogical Issues.

When the studies conducted according to the level of education in studies involving keywords about education level were examined, it was observed that the most researches were conducted at the Higher Education level and the least at the Pre-school and Primary education level. It can be assumed that the reason for more studies at the Higher Education level is that current and complex technologies can be used more easily at this level and that the researchers work at this learning level. Again, it can be assumed that the lack of studies conducted at the pre-school and primary education level can be associated with the difficulty of the practices at these level and ethical factors. 
As a result of the study, some suggestions can be made for future studies. Before that, it should be noted that there were limitations in the study and that studies may be conducted to eliminate these limitations in the future. The documents scanned in the study are limited to journals that publish reviews in educational technology determined by the researchers, so this should be considered in generalizing the study results. The studies conducted in educational technology are not limited to the publications included in this research. It may be suggested to have more publications in future research on this subject. Besides, it is thought that increasing the number of publications in the field of educational technology will contribute to the development of the area. The articles discussed in this study were examined in terms of titles and keywords to determine subject trends, apart from publication information. In subsequent studies, articles published in educational technology can be analyzed using different features such as method-technique. Again, this study covered the last five years in terms of publication date. In subsequent studies, articles published in a more extended period can be included in the study. As time passes, similar studies can be conducted to observe current results and changes.

\section{References}

Akademi, Medya. (2020). 2020 Sosyal Medya Kullanıcı Sayıları [2020 Social Media User Counts]. 3 Şubat 2020. (Accessed: 18 November 2020). https://medyaakademi.com.tr/2020/02/03/2020-sosyal-medya-kullanici-sayilari/

Alkan, C., \& Hacıŏlu, F. (1995). Öğretmenlik uygulamaları: öğretim teknolojisi [Teaching practices: instructional technology]. İstanbul: Alkım Yayınevi.

Alkan, C. (2011). Eğitim Teknolojisi [Education Technology]. (8.Baskı)Ankara: Anı Yayıncllık.

Alper, A., \& Gülbahar, Y., (2009). Trends And Issues In Educatıonal Technologies: A Review Of Recent Research In Tojet. The Turkish Online Journal of Educational Technology - TOJET, April 2009, 126-135.

Altheide, D. L., \& Schneider, B. (1996). Process of qualitative document analysis. Qualitative media analysis, 23-41.

Berrocoso, J., Arroyo, M., Videla, C., \& Cevallos, M. (2020). Trends in Educational Research about e-Learning: A Systematic Literature Review (2009-2018). Sustainability, 12(12) 1-23.

Bowen, G. A. (2009). Document analysis as a qualitative research method. Qualitative research journal, 27-40.

Caffarella, E. P. (1999). The major themes and trends in doctorial dissertation research in educational technology from 1977 through 1998. Educational Media andTechnology Yearbook, 25, 14-25.

Cleary, A. (1976). Education Technology: implications for Early and Special Education. New York: John Wiley.

Costa, F. A. (2007). Educational technologies: Analysis of master dissertation carried out in Portugal. Educational Sciences Journal, 3, 7-24.

Dieuzeide, H. (1971). Educational technology: Sophisticated, adapted and rational technology. Paris International Commission on the Development of Education, UNESCO. 
Erdoğmuş, U. F., \& Çağıltay, K., (2009). Türkiye'de Eğitim Teknolojileri Alanında Yapılan Master Ve Doktora Tezlerinde Genel Eğilimler [General Trends in Master and Doctorate Theses in Educational Technologies in Turkey]. Akademik Bilişim'09 - XI. Akademik Bilişim Konferansı Bildirileri, Şubat 2009, 389-393.

Göktaş, Y., Küçük, S., Aydemir, M., Telli, E., Arpacık, Ö., Yıldırım, G., \& Reisoğlu, İ. (2012). Türkiye'de eğitim teknolojileri araştırmalarındaki eğilimler: 2000-2009 dönemi makalelerinin içerik analizi [Trends in educational technology research in Turkey: Content analysis of 2000-2009 articles]. Kuram ve Uygulamada Eğitim Bilimleri Dergisi, 12(1), 177 199.

Greenhow, C., Galvin, S. M., \& Staudt Willet, K. B. (2019). What Should Be the Role of Social Media in Education? Policy Insights from the Behavioral and Brain Sciences, 6(2), 178-185. https://doi.org/10.1177/2372732219865290

Hew, K. F., Kale, U., \& Nari, K. (2007) Past Research in Instructional Technology: Results of a content analysis of empirical studies published in three prominent instructional technology journals from the year 2000 through 2004. Journal of Educational Computing Research, 36(3), 269-300.

Januszewski, A., \& Molenda, M. (2008). Educational technology: A definition with commentary. New York: Lawrence Erlbaum Associates.

Çakmak, E. K., Özüdoğru, G., Bozkurt, Ş. B., Ülker, Ü., Ünsal, N. Ö., Boz, K., ... \& Bahadır, H. (2016). 2014 Yılında eğitim teknolojileri alanındaki yayımlanan makalelerin incelenmesi [Examining the articles published in the field of educational technologies in 2014]. Eğitim Teknolojisi Kuram ve Uygulama, 6(1), 80-108.

Kılıç Çakmak, E., Kukul, V., Çetin, E., Berikan, B., Kandemir, B., Pamukçu, B. S., Taşkın, N., \& Marangoz, M. (2015). 2013 Yılı Eğitim Teknolojileri Araştırmalarının İncelenmesi: AJET, BJET, C\&E, ETRD, ETS ve L\&I Dergileri [Analysis of 2013 Educational Technology Research: AJET, BJET, C\&E, ETRD, ETS and L\&I Journals], Eğitim Teknolojisi Kuram ve Uygulama, 5(1), 128- 160.

Kıral, B. (2020). Nitel Bir Veri Analizi Yöntemi Olarak Doküman Analizi [Document Analysis as a Qualitative Data Analysis Method]. Siirt Üniversitesi Sosyal Bilimler Enstitüsü Dergisi, 8(15), 170-189.

Krull, G., \& Duart, J. (2017). Research Trends in Mobile Learning in Higher Education: A Systematic Review of Articles (2011 - 2015). International Review of Research in Open and Distributed Learning, 18(7). https://doi.org/10.19173/irrodl.v18i7.2893

Kurt, İ. (2019). Öğretmenlerin Lise Okul Müdürlerinin Teknoloji Liderliği Yeterliliklerine İlişkin Görüssleri [Opinions of Teachers on Technology Leadership Competencies of High School Principals] (Unpublished Master's Thesis). Marmara University, İstanbul.

Lai, J. W., \& Bower, M. (2020). Evaluation of technology use in education: Findings from a critical analysis of systematic literature reviews. Journal of Computer Assisted Learning, 36(3), 241-259.

Latchem, C. (2006). Editorial: A content analysis of the British Journal of Educational Technology. British Journal of Educational Technology, 37(4), 503-511.

Masood, M. (1997). A ten year analysis: Trends in traditional educational technology literature. Malaysian Online Journal of Instructional Technology, 1(2), 1823-1844. 
Numanoğlu, G. (1995). Bir Eğitim Ortamı Olarak Bilgisayardan Yararlanmada Politika ve Stratejiler [Policies and Strategies in Utilizing Computer as an Educational Environment]. (Unpublished Master's Thesis). Ankara University. Ankara.

Öztemel, E. (2018). Eğitimde yeni yönelimlerin değerlendirilmesi ve eğitim 4.0 [Evaluation of New Trends in Education and Education 4.0]. Üniversite Araştırmaları Dergisi, 1(1), 25-30.

Roblyer, M. D., \& Doering, A. H. (2013). Integrating educational technology into teaching (6th Ed.). Boston: Pearson.

Ross, S. M., Morrison, G. R., \& Lowther, D. L. (2010). Educational technology research past and present: Balancing rigor and relevance to impact school learning. Contemporary Educational Technology, 1(1), 17-35.

Shukla, T., Dosaya, D., Nirban, V. S., \& Vavilala, M. P. (2020). Factors extraction of effective teaching-learning in online and conventional classrooms. International Journal of Information and Education Technology, 10(6), 422-427.

Şimşek, A., Özdamar, N., Becit, G., Kılıçer, K., Akbulut, Y. ve Yıldırım, Y. (2008). Türkiye'deki eğitim teknolojisi araştırmalarında güncel eğilimler. Selçuk Üniversitesi Sosyal Bilimler Enstitüsü Dergisi, 19, 439-458.

Şimşek, A., Özdamar, N., Uysal, Ö., Kobak, K., Berk, C., Kılıçer, T., \& Çiğdem, H. (2009). İki binli yıllarda Türkiye'deki eğitim teknolojisi araştırmalarında gözlenen eğilimler [Trends observed in educational technology research in Turkey in the 2000s]. Kuram ve Uygulamada Eğitim Bilimleri, 9, 941-966.

Tankovska, H. (2021). Most popular social networks worldwide 2020, by reach. 2021. [Accessed: 19 March 2021]. https://www.statista.com/statistics/274773/global-penetration-ofselected-social-media-sites/

Wittich, W. A., \& Schuller, C. F. (1979). Instructional technology, its nature and use. Harper \& Row.

Yufeia, S. S. (2020). Review of the Application of Artificial Intelligence in Education. International Journal of Innovation, Creativity and Change, 12(8), 548-562. 


\section{Appendix}

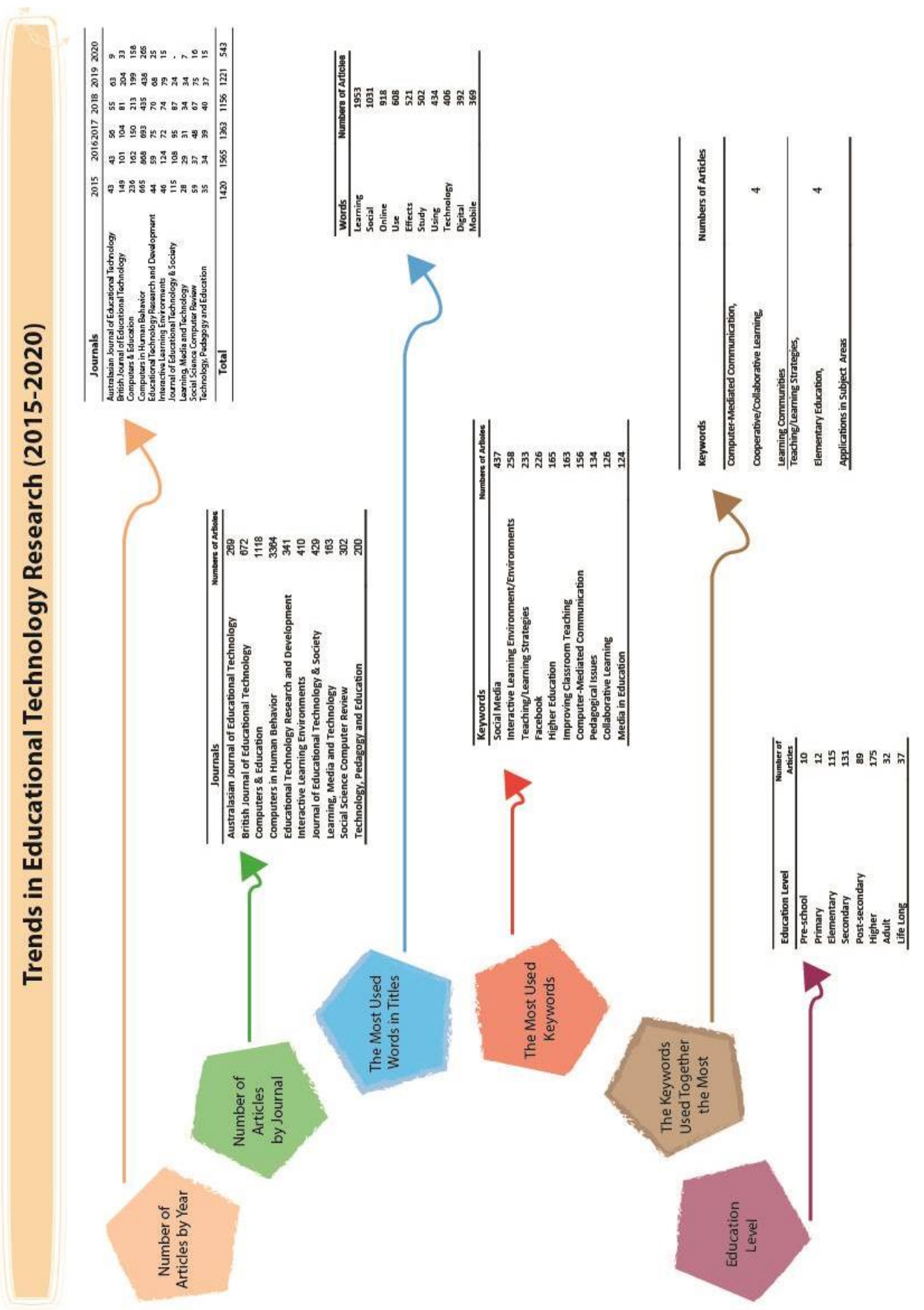

Appendix 1. Infographic of Research Findings 
In the writing process of the study titled "Topic Trends in Educational Technology Research (2015-2020)", the rules of scientific, ethical and citation were followed; it was undertaken by the authors of this study that no falsification was made on the collected data. "Sakarya University Journal of Education Journal and Editor" had no responsibility for all ethical violations to be encountered, and all responsibility belongs to the authors and that the study was not submitted for evaluation to any other academic publishing environment.

\begin{tabular}{|l|}
\hline Statement of Contribution of Researchers to the Article: \\
1st author contribution rate: $10 \%$ \\
2nd author contribution rate: $10 \%$ \\
3rd author contribution rate: $10 \%$ \\
4th author contribution rate: $10 \%$ \\
5th author contribution rate: $10 \%$ \\
6th author contribution rate: $10 \%$ \\
7th author contribution rate: $10 \%$ \\
8th author contribution rate: $10 \%$ \\
9th author contribution rate: $10 \%$ \\
10th author contribution rate: $10 \%$ \\
\hline Conflict of Interest Statement: \\
There is no conflict of interest. \\
\hline Statement of Financial Support or Acknowledgment: \\
No financial support was received from any institution for this study. \\
\hline
\end{tabular}

